\title{
Recurrent Malignant Myoepithelioma
}

National Cancer Institute

\section{Source}

National Cancer Institute. Recurrent Malignant Myoepithelioma. NCI Thesaurus. Code C162732.

The reemergence of a malignant myoepithelioma after a period of remission. 